\title{
The implementation of RADEC learning model in thematic learning to increase the concept understanding of electrical phenomenon
}

\author{
Wati Rohmawatiningsih 1, a *, Indriyani Rachman 2, b, Kodama Yayoi ${ }^{2, c}$ \\ ${ }^{1}$ SD Negeri Dayeuhkolot 07. Jalan Mama Yuda, Dayeuhkolot, Bandung, 40258, Indonesia \\ ${ }^{2}$ The University of Kitakyushu. Kitagata, Kokuraminami Ward, Kitakyushu, Fukuoka 802-8577, Japan \\ ${ }^{a}$ wati.rohmawatiningsih@yahoo.co.id; ${ }^{b}$ r-indriyani@kitakyu-u.ac.jp; ${ }^{c}$ kodama@kitakyu-u.ac.jp \\ * Corresponding Author
}

\begin{abstract}
This research is motivated by the large number of elementary school classrooms that do not offer quality science experiences to students so that it has an impact on students' low understanding of the science concept. The RADEC (Read-Answer-DiscussExplain And Create) learning model seems suitable for increasing students' understanding of science concepts. This learning model has scientific stages that encourage the construction of students' knowledge. This study aims to analyze the increased understanding of the concept of electrical phenomena through the application of the RADEC learning model. The study involved twenty-eight grade 5 students in the 2019-2020 academic year. Quasi-experimental method with one-group pretest-postest design was used in this study. To find out the understanding of students' concepts about electrical phenomena, tests were carried out before and after the implementation. This study uses descriptive analysis to analyze data collected before and after implementation. From the results of the analysis, it is known that students' understanding of the concept of electrical phenomena after the implementation of the RADEC learning model is higher than before. Thus, it can be concluded that the application of the RADEC learning model can improve students' conceptual understanding of electrical phenomena.

Keywords: RADEC, concept understanding, knowledge construction
\end{abstract}

How to Cite: Rohmawatiningsih, W., Rachman, I., \& Yayoi, K. (2021). The implementation of RADEC learning model in thematic learning to increase the concept understanding of electrical phenomenon . Momentum: Physics Education Journal, 5(2), 121-131. https://doi.org/10.21067/mpej.v5i2.5412

\section{Introduction}

Natural science education has a very important role for students to become qualified human beings who are able to solve various kinds of problems in everyday life. As expressed by John Dewey, education is a necessity of life and a means of preparing students to face various tasks and responsibilities in the future. Providing science education at an early age supports language development, early literacy, math skills, and improves conceptual understanding in early childhood (Gerde et al., 2013). Thus, the role of science is to equip students with various knowledge and skills to be able to face various challenges in the future. The Indonesian Ministry of Education and Culture (Kementerian Pendidikan dan Kebudayaan, 2014) states that science education is integrated with other core subjects in the primary school curriculum in Indonesia. Thus, students can predict and interpret various environmental problems from various points of view. The end result is an increase and balance between the ability to be good human beings (soft skills) and humans who have the skills and knowledge to live well (hard skills).

Correct understanding of scientific concepts and content at the elementary school level is necessary so that students can effectively study science at a higher level or natural phenomena that occur in life. But in fact, most students have difficulty understanding the concept of science, and even 
misconceptions occur even though this topic has been given to the previous class (Akbas \& Gencturk, 2011; Rohmawatiningsih et al., 2018; Şahin \& Çepni, 2011). Misunderstandings occur on various science topics, including electricity (Redhead, 2018; Turgut et al., 2011; Widodo et al., 2018). They found that students had misconceptions about concepts such as current, resistance, potential difference, electricity, sources and electrical energy. This is very dangerous because their misconceptions will continuously interact with other scientific concepts and can lead to other conceptions of other scientific concepts (Akbas \& Gencturk, 2011). Student misconceptions in science are closely related to the way teachers teach. Many elementary school teachers do not offer quality scientific experiences to their students, making it difficult for students to understand the concept of science (Gerde et al., 2013). This learning only focuses on knowledge retention that suppresses student motivation and subjectivity, while teachers do not provide space for students to think independently (Beckmann \& Weber, 2016; JaleniauskienL', 2016). This of course will result in passive learners resulting in low performance (Vlassi \& Karaliota, 2013).

There is no doubt that a science teacher plays a key role in improving the learning outcomes of his students. In line with the problems of education in primary schools described above, it is necessary to have an innovative learning model that is easily implemented by schools in Indonesia and can develop students' conceptual understanding. According to Jones et al. (2012) and Dickerson et al. (2014), students' conceptual understanding can be built by an authentic investigation. It can strengthen students' understanding of natural phenomena (Dickerson et al., 2014; Hong et al., 2014). Learning strategy based on a constructivism approach in which new knowledge is built based on prior student knowledge is needed to supports the students' conceptions changes. It is important that teachers have previous knowledge of students in order to create a discourse that will encourage the student to develop understanding of a scientific concept (Inaltekin \& Akcay, 2021). Therefore, we selected an alternative learning model that is considered in accordance with these learning criteria as an effort to increase students' conceptual understanding, namely through the Read- Answer - Discuss - Explain and Create (RADEC) learning model.

RADEC learning model was first introduced by Sopandi (2017) at an international conference in Kuala Lumpur, Malaysia. The name of this model is adjusted to the syntax of Read, Answer, Discussion, Explain, and Create (RADEC). The Vygotsky's theory of social constructivism is the basis for the development of this model. According to this theory, students can develop their cognitive abilities through their interactions with the social environment. In implementation of RADEC model, students are involved in critical reading activities, social (teacher and student) interaction, scientific investigation, and product creation. Their actively form meaningful knowledge structures based on their previous knowledge. It is important that teachers are aware of the diversity of ideas that students adopt while planning appropriate activities in the classroom. Sopandi (2017) sated that the syntax in this model is very easy to memorize. This model fits into the Indonesian education system which requires students to understand many scientific concepts in a limited time.

Some previous study has also proven that RADEC learning model has a positive impact on science learning. The results of the study show that the RADEC learning model can improve students 'critical thinking skills (Pratama et al., 2019) and creative thinking skills (Jumanto et al., 2018; Wulandari et al., 2020). It appears that these studies only examine the effect of the RADEC learning model on the skills competency. While other competencies have not been researched other aspects, including conceptual understanding. In fact, developing science concepts is an essential part of science learning. Science conceptual understanding is needed as a foundation for acquiring high order thinking like critical and creative thinking skills in solving problems they face. Related to these advantages, it is hoped that the RADEC learning model can improve students' conceptual understanding.

\section{Method}

The method used in this study was a quasi-experimental method with the one-group pre-test post-test design. This study used an experimental class that was given treatment, namely the RADEC 
learning model. A conceptual understanding test was given before and after implementing the RADEC learning. The one-group pre-test - post-test design (Fraenkel et al., 2012) can be seen in Figure 1.

\begin{tabular}{|ccc|}
\hline $\mathbf{O}_{1}$ & $\mathbf{X}$ & $\mathbf{O}_{2}$ \\
\hline Pretest & Treatment & Postes \\
\hline
\end{tabular}

Figure 1. One-Group Pre-test - Post-test Design (Fraenkel et al., 2012)

Information:

$\mathrm{O}_{1}$ : Pre-test to see the students' concept understanding of electrical phenomenon before the RADEC learning model implementation.

$\mathrm{X}$ : Implementation of the RADEC learning model.

$\mathrm{O}_{2}$ : Post-test to see the students' concept understanding of electrical phenomenon after the RADEC learning model implementation.

The research subjects were all $5^{\text {th }}$ grade students in one of the primary schools in Bandung which amounted to 28 students with an age range of 11 to 12 years old. The considerations for selecting 5th grade students to become sample are that children at this age are able to use their logic, plan organized behaviour, accept plans or goals for activities, and link knowledge and actions in the plan (Desmita, 2012). In addition, at this class level there is electrical concept that must be mastered as a foundation for learning other topics at the next level.

To determine students' understanding of electrical phenomena concepts, a conceptual understanding test was administered before and after the implementation of RADEC learning model. There were 5 items questions that given in essay form. In addition, the observation conducted to observe the implementation of the RADEC learning model. Two teachers from the school participated in observation.

The collected data were analyzed using a descriptive analysis approach. The formula for calculating the grade of the students' concept understanding of electrical phenomenon is as follows.

Grade $=\frac{\text { Score Acquisition }}{\text { Maximum Score }} \times 100$

The category for the students' concept understanding of electrical phenomenon grades are presented in Table 1.

Table 1. Categories of Conceptual Understanding

\begin{tabular}{ccc}
\hline No. & Grade & Category \\
\hline 1. & $81-100$ & Very good \\
2. & $61-80$ & Good \\
3. & $41-60$ & Moderate \\
4. & $21-40$ & Less \\
5. & $0-20$ & Very less \\
\hline
\end{tabular}

Data research procedures in this study are shown in Figure 2. Figure 2 shows that in general research procedure consists of three stages, namely the preparation, implementation, and final stages. The first stage was the preparation, we studied the literature regarding the research variables and analyzed school as research subject. The purpose of the analyze phase is to identify the probable causes for a performance gap. The analyze phases were included: (1) Analyze science materials, which aims to identify science materials taught at school through documents and interview; (2) Audit available resources, to identify all types of resources that will be required to complete the entire research that conducted through interviews with class teachers and principal; (3) Analyze learning instruction, which aims to identify learning instruction used in learning science at schools as research subject that conducted through interviews with class teachers and learning observation; and (4) Analyze learners, which aims to identify student characteristics including student motivation, attitudes, skills, and numbers of students. This was conducted through learning observation and interviews with classroom teachers. After obtaining the analysis result data, we determined a learning model needs to be developed based on the results of the analysis. In this study, RADEC learning model was selected to support thematic learning which consists of Science, Bahasa Indonesia and 
Mathematics subjects tied to one theme, namely "Electricity Around Us". Then, we designed the lesson plan, worksheet, and evaluation instruments based on analyzed data and study of literature. Then, these instruments were developed and validated by experts to test its feasibility. Input from experts were used as the basis for improvement that these instruments are suitable for this research.

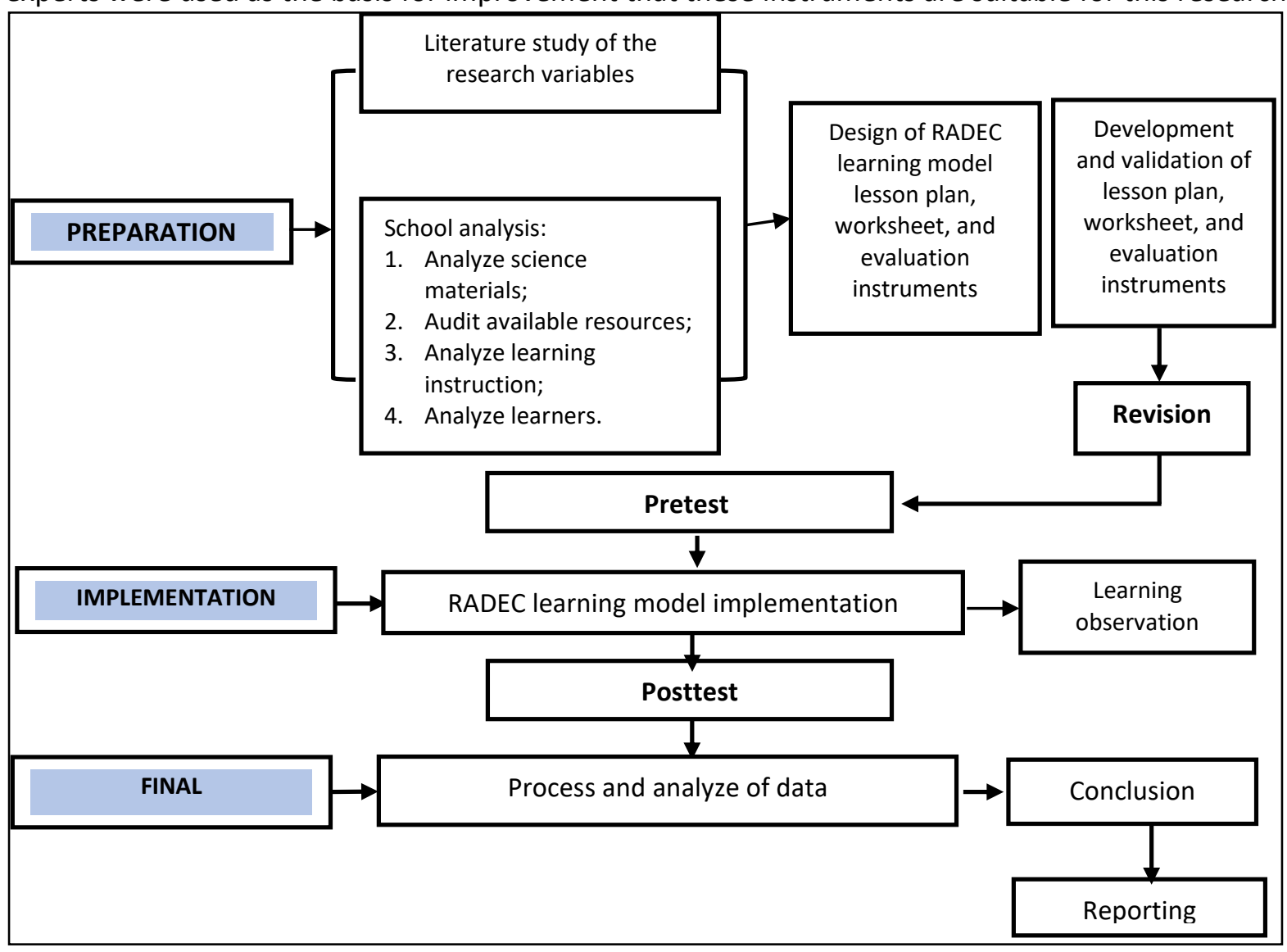

Figure 2. Research Procedures

The second stage of this research was the implementation stages, where RADEC learning model was carried out by researcher. Students were previously given a pretest to see the students' concept understanding of electrical phenomenon before learning. During the learning, two teachers observed the implementation of RADEC learning model. After that, students were given post-test to see the students' concept understanding of electrical phenomenon after implementation. The last stage was the final stage, where the collected data then processed and analyzed so we can draw conclusion and make a research report.

\section{Results and Discussion}

The results of the research and discussion in this study are presented based on the results of the analysis of the research conducted. The explanation will be divided inti three parts, namely: Implementation of the RADEC Learning Model in Thematic Learning to Increase the Students' Concept Understanding of Electrical Phenomenon, Students' Concept Understanding of Electrical Phenomenon Before and After the Implementation of the RADEC Learning Model in Thematic Learning, and Students' Concept Understanding of Electrical Phenomenon in Terms of Reading Activities After the Implementation of RADEC Learning Model

\section{Implementation of the RADEC Learning Model in Thematic Learning to Increase the Students' Concept Understanding of Electrical Phenomenon}

The RADEC learning model in this study was applied in thematic learning consisting Science, Indonesian and Mathematics subjects that bound by a theme, namely "Electricity Around Us". The 
syntax of RADEC learning model are read, answer, discuss, explain, and create (Sopandi, 2017), with details of the activities as follows.

Read

At read stage, students read information from the printed information texts on the topic "Electricity Around Us" and "Data Presentation" which had been given the day before learning began. They were also allowed to read other information sources from internet or books. This activity aims to guide the students in understanding information provided with pre-learning questions. These questions associated with teaching material. The read stage was carried out independently by students at home without the other helps.

The students' concept understanding of electrical phenomenon can be built at read stage. It occurs students' conception change that involves a cognitive process such as adapting and restructuring the concepts that students have had before to be a new conception. This is in line with the statement from Küçükoğlu (2013) that reading activity is a key element in developing student understanding of content. Reading stage in RADEC learning model introducing critical literacy pedagogy for the students. It is needed in classroom curriculum (Riasati \& Mollaei, 2012). A reading literacy can develop student skills to understand hidden meanings, reconstruct their knowledge, and examine science phenomena from multiple perspective (Svetlana \& Olga, 2017). Therefore, the students' concept understanding of electrical phenomenon can improve at this stage.

Answer

At answer stage, students answered pre-teaching questions based on the knowledge obtained by the reading activity at home. Pre-teaching questions are arranged in students' worksheet. Preteaching questions were given in this study containing low-thinking skills to high-thinking skills questions with indicators: (1) standard vocabulary and main sentences for Indonesian Language; (2) electricity phenomenon and energy sources for Science; and (3) the processing and presentation of data for Mathematics. These questions can stimulate students' thinking (Rashid \& Qaisar, 2016). Students must answer questions after their reading activities at their home independently before the class session is conducted. Students can ask other students or teacher to explain the materials that cannot be mastered by them during class sessions. At answer stage, students can identify which parts of teaching material are considered easy or difficult. Student's conceptual understanding of electrical phenomenon increase when they tried to answer the questions based on the knowledge obtained by the reading activity. They recalled what have they learnt. If they did not remember, they reread the text information. This will deepen their understanding. Their answer is a prior student knowledge, needed to supports the students' conceptions changes. It is important that teachers have previous knowledge of students in order to create a discourse that will encourage the student to develop understanding of a scientific concept (Inaltekin \& Akcay, 2021).

\section{Discuss}

At discuss stage, students discussed about their answers to pre-teaching questions in their group. The students who succeed in carrying out certain tasks motivated to provide a guidance to other friends who have not mastered the teaching material. According to (Azmitia, 1988), colleagues often carry different abilities and they tend to observe and imitate colleagues who are more skilled. Thus, when students who are more skilled guide other students who are not experts, knowledge internalization will occur in students who are not experts which can increase their concepts understanding. Activity of discuss stage shown in Figure 3.

During discussion activities, the teacher must ensure that there is effective communication between students in each group to get the correct answer. This activity can expose students to broaden various perspectives and provide opportunities for them to express their thoughts. Discussing can provide them a broader perspective that helps them interpret real-world problems properly (Stefanova et al., 2017). 


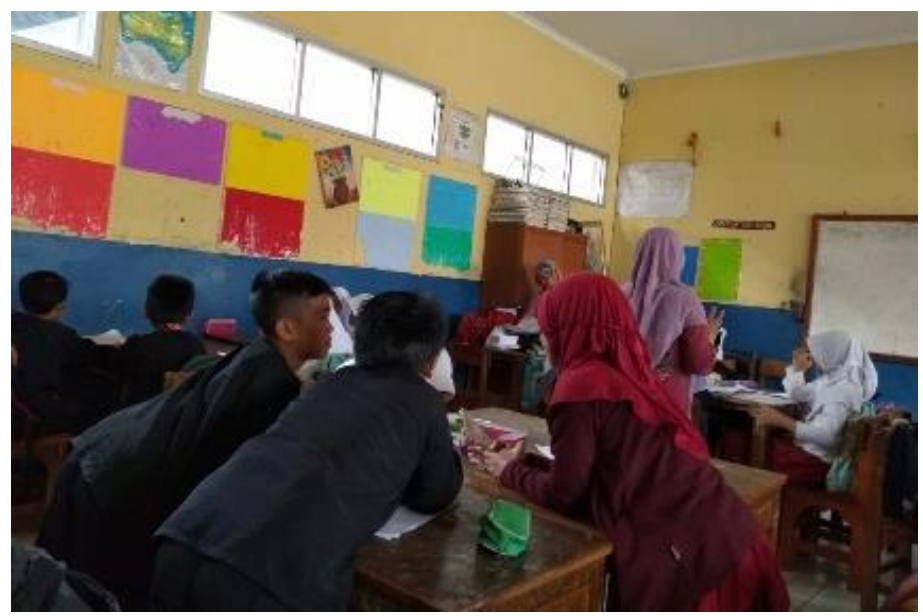

Figure 3. Discuss Stage

Explain

At explain stage, presentation of discussion results was conducted. Representatives students who have mastered the learning indicators asked to explain important concepts in front of the class. The teacher ensures that the presenter explains scientifically and correctly and the other students understand the explanation. In this activity, other students are recommended to give questions, opinions, or add information to the presenting group. Then, teacher gave reinforcement and gave an explanation about important concepts which cannot be mastered by all students. It can be seen that at this stage students explained and debated their various thoughts, then searched for the most appropriate answers activities. These activities can improve and increase their knowledge.

Create

At create stage, teacher facilitated students to use their knowledge that has been mastered to generate creative ideas in an investigation activity. The teacher as a facilitator tries to encourage students to accept more responsibilities for their learning experiences. Teacher gave contextual problems related to the scarcity of fossil fuels for electricity in worksheet. The teacher provided various natural ingredients such as cucumbers, oranges, lemons, potatoes, and bananas as an alternative source of electrical energy. In addition, the teacher also provides an electrical circuit component. Teacher gave an investigative question "Which fruit is the most effective source of electrical energy?", which students must answer that question as a hypothesis. Then, students conducted an experiment activity to test their hypothesis that shown in Figure 4.

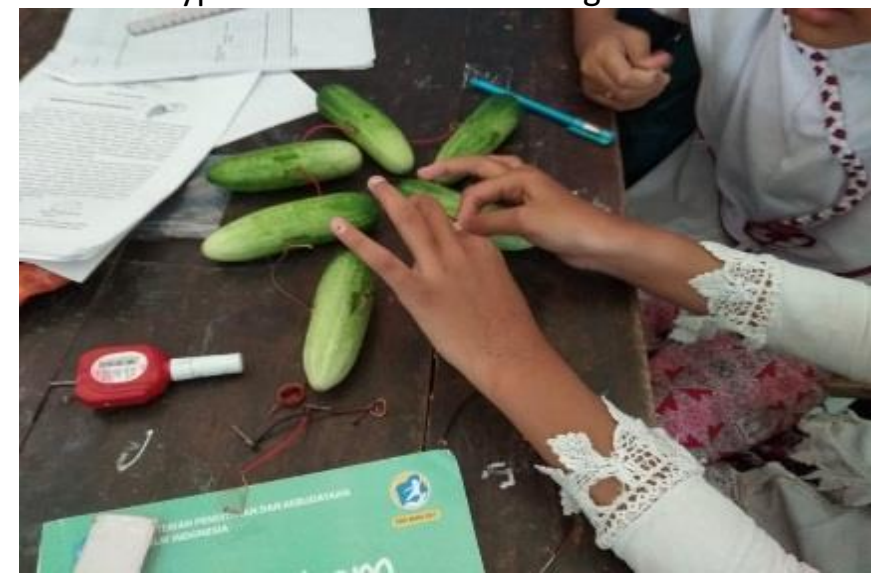

Figure 4. Create Stage

Figure 4 shows students conducted an investigation regarding electrical phenomenon using several types of fruit. The fruits used were cucumbers, oranges, lemons, potatoes, and bananas. Students investigated how many fruits are needed to light one lamp for each type of fruit in order to 
obtain the best fruit for creating electrical energy. After the experiment, students presented the observed data into tables and graphs as an implementation of mathematical material, and presented them in class. It appears at this stage, students were involved in predicting, giving hypothesis, planning and conducting investigation to test their hypothesis, making observations, interpreting, and communicating. These all activities describe a science process. According to Harlem and Elstgeest (1993), science processes can help students to develop their ideas or concepts. At this stage, students understood the science concept that a source of electricity can be generated from fruits not only battery. These fruits contain acid, an electrolyte which can conduct electricity. The more acidic (the smaller the $\mathrm{pH}$ value), the greater the solution's electric current and the greater the $\mathrm{pH}$ value, the smaller the value of the solution's electric current. Scientific inquiry through create stage in RADEC learning model provides meaningful experiences that integrate Indonesian language, mathematic, and science education.

Students' Concept Understanding of Electrical Phenomenon Before and After the Implementation of the RADEC Learning Model in Thematic Learning

A concept understanding of electrical phenomenon test questions was given to twenty-eight students attending 5th grade, before (pre-test) and after learning using the RADEC model (post-test). The result shows that the students' concept understanding of electrical phenomenon on the posttest is better than the pre-test. This can be seen in the Figure 5 .

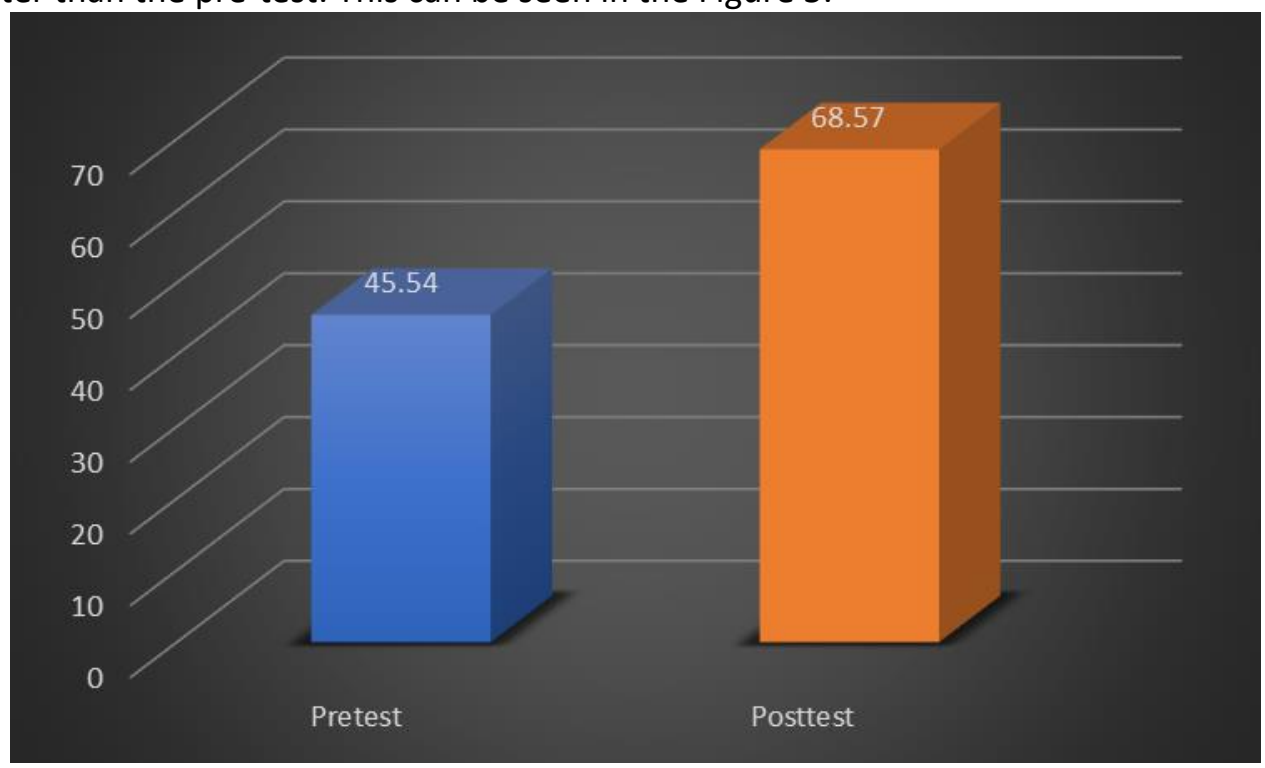

Figure 5. The Mean of Students' Concept Understanding

Based on Figure 5, it is known that the students' concept understanding of electrical phenomenon has improved after implementing RADEC learning model. The average students' pre-test is 33.57 in less category. Meanwhile, the average students' post-test is 72.14 in good category. Through using RADEC learning model, students may have clarified, modified, or developed their initial ideas or concepts of electrical phenomenon. There is a scientific process in RADEC learning model that students have a better understanding of science concepts (Gerde et al., 2013). Every stage of RADEC involved the students in constructing their knowledge. It expands and deepens their thinking about the concepts being studied. At read stage, students obtain information about electrical phenomena through reading the text and internet information. It can help students how to perform literary interpretation, analysis, and develop a greater understanding (Magulod, 2018). Students were also involved in social interaction at the discussion, explain, and create stages. Students broaden various perspectives and express their thoughts that can develop their cognitive abilities (Vygotsky, 2012).

At the create stage, students were faced with contextual problems related to the electrical phenomenon and were required to carry out scientific investigation through an experiment. These create cognitive conflicts in students that needed in the accommodation stage to obtain new con- 
cepts and change student conceptions (Posner et al., 1982). However, many experts believe that the authentic task is the best way to correct concept errors that exist in students and strengthen students' understanding of natural phenomena (Hong et al., 2014; Pintrich et al., 1993).

Students' Concept Understanding of Electrical Phenomenon in Terms of Reading Activities After the Implementation of RADEC Learning Model

Increase students' concept understanding about electrical phenomenon after RADEC learning model implementation can also be seen from the difference in the average pre-test and post-test in terms of reading activities of students during pre-learning. The average of students' concept understanding in terms of students' reading activities can be seen in Figure 6.

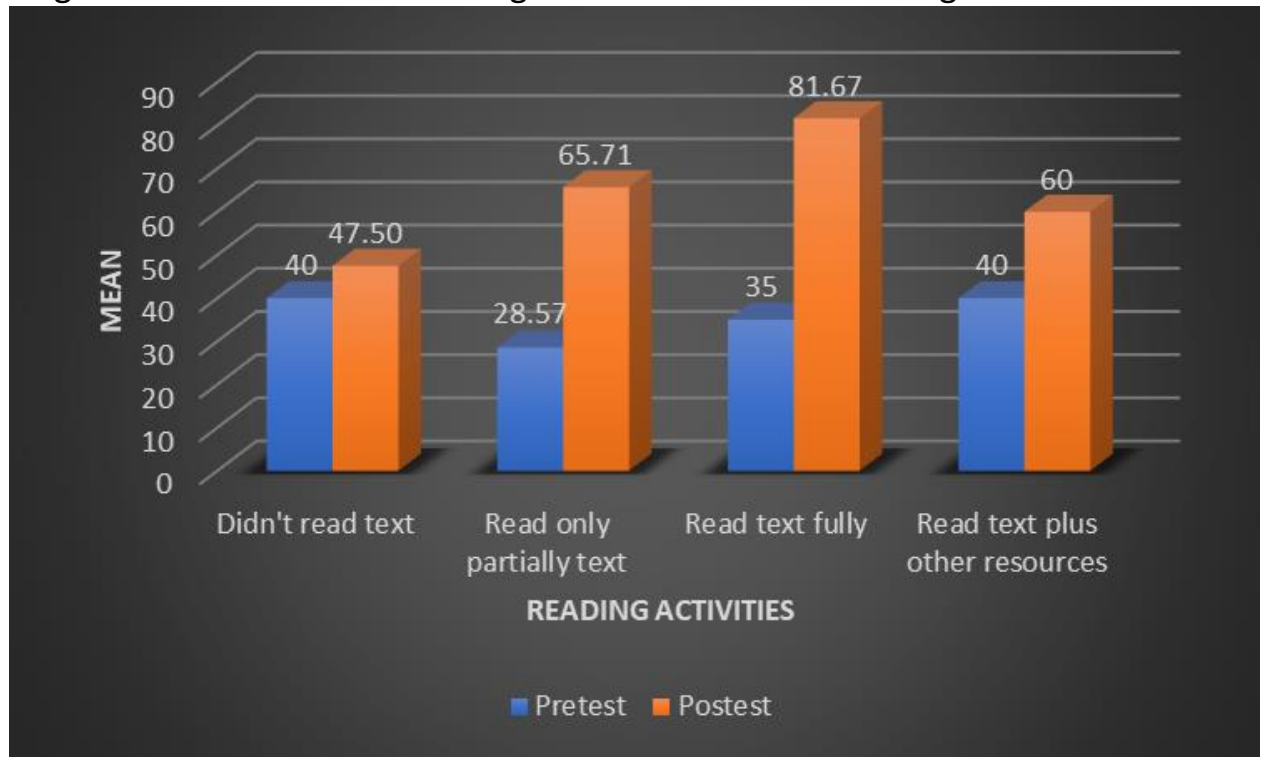

Figure 6. The Mean of Students' Concept Understanding in Terms of Reading Activities

Figure 6 shows that there is an increase in the rate of understanding of concepts in each type of reading activity. There is the striking difference in conceptual understanding between students who did not read text, read text fully, read only partially text, and read text plus other resources. The lowest post-test mean found in students who did not read text in pre-learning reaches 47,50 in less category. The increase of concept understanding in students who did not read text reaches 7.5. It is the lowest increase of conceptual understanding. Meanwhile, the highest post-test mean found in students who read text fully in pre-learning is 81,67 in very good. After RADEC model implementation, the increase of concept understanding in students who read text fully reaches 46.67 . It is the highest increase than others. Students who read fully at read stage obtain new ideas and new ways of looking at ideas from the text they read. According to Stefanova et al. (2017), by reading text, students can understand hidden meanings, reconstruct their conception, and examine phenomena from multiple points of view (Stefanova et al., 2017).

In this study, we also found the concept understanding average of students who read text plus other resources is only 60 and the increase is only 20 from the pre-test and post-test results. It is lower than the students who only read text partially and the students who read fully. As many as 1 student from a total of 26 students read the text plus other sources via Google. Logically, students who read the text plus other sources should be better than others. We tried to point out several possible causes. First, student did not completely read the text or other sources. Second, students only read but did not try to understand what they are reading. In other words, the student is not a good reader. According to Küçükoğlu (2013), good readers are actively involved with the text, and they are aware of the processes they use to understand what they read. And third, student did not read other reading sources related to the electrical phenomenon topic but other topics in thematic learning as main sentences for Indonesian Language or the processing and presentation of data. In searching for electronic sources of information, the teacher should provide a relevant website 
address instead of asking students to search for it independently. Thus, they can focus on the material they have to learn. These possibilities can occur because at the read stage students read various sources at home independently without teacher guidance so that teachers cannot directly monitor student behavior, what they read, and how their reading comprehension ability. These indicate the drawbacks of the RADEC learning model. The teacher should be able to guide the reading process of students directly in class learning session. Group practice or partner practice can be used in a class to improve student comprehension. In other words, the read stage of the RADEC learning model should be carried out in the classroom so that teachers can monitor student performance, motivate, intervene at the right time, guide, and select relevant learning resources. This shows that the reading stage in the RADEC learning model has an impact on concept understanding of electrical phenomenon. This concept will be implemented to investigative activities at the other stages.

\section{Conclusion}

From the data analysis, it can be concluded that there is an increase of students' concept understanding of electrical phenomenon through the implementation of RADEC learning model. This learning model involves students actively in constructing their concept knowledge through the five stages of RADEC, namely Read, Answer, Discuss, Explain, and Create.

Related to the drawbacks of the RADEC learning model found in this study that students who read text plus other resources have lower conceptual understanding than others. Since it is very important to conduct further research, incorporation the Read stage into the learning session in the classroom is needed to increase concept understanding more effectively.

It is important to make the RADEC learning model as an alternative science learning in thematic learning for primary school. Through this learning model, students actively interacted with literature, high level questions, social (teacher and student), scientific process, and product creation. It can develop students' reading literacy, social competence, mathematical literacy, science process skills, conceptual understanding, and high order thinking that support their competences. However, RADEC learning model greatly assists teachers and students in science learning.

\section{References}

Akbas, Y., \& Gencturk, E. (2011). The effect of conceptual change approach to eliminate 9th grade high school students' misconceptions about air pressure. Educational Sciences: Theory and Practice, 11(4), 2217-2222.

Azmitia, M. (1988). Peer interaction and problem solving: when are two heads better than one? Child Development, 59(1), 87-96. https://doi.org/10.1111/j.1467-8624.1988.tb03197.x

Beckmann, J., \& Weber, P. (2016). Cognitive presence in virtual collaborative learning. Interactive Technology and Smart Education, 13(1), 52-70. https://doi.org/10.1108/ITSE-12-2015-0034

Desmita, D. (2012). Psikologi perkembangan peserta didik. Rosdakarya.

Dickerson, D. L., Stewart, C. O., Hathcock, S., \& McConnell, W. (2014). The nature and role of science kits in affecting change in public attitude toward understanding of science. In Communicating Science to the Public (pp. 47-62). Springer Netherlands. https://doi.org/10.1007/978-94-0179097-0 4

Fraenkel, J. R., Wallen, N. E., \& Hyun, H. H. (2012). How to design and evaluate research in education. McGraw-Hill.

Gerde, H. K., Schachter, R. E., \& Wasik, B. A. (2013). Using the scientific method to guide learning: an integrated approach to early childhood curriculum. Early Childhood Education Journal, 41(5), 315-323. https://doi.org/10.1007/s10643-013-0579-4

Harlem, W., \& Elstgeest, J. (1993). UNESCO Source Book for Science Teaching in the Primary School. Unipub. 
Hong, J.-C., Hwang, M.-Y., Liu, M.-C., Ho, H.-Y., \& Chen, Y.-L. (2014). Using a "prediction-observationexplanation" inquiry model to enhance student interest and intention to continue science learning predicted by their Internet cognitive failure. Computers \& Education, 72, 110-120. https://doi.org/10.1016/j.compedu.2013.10.004

Inaltekin, T., \& Akcay, H. (2021). Examination the Knowledge of Student Understanding of Pre-Service Science Teachers on Heat and Temperature. International Journal of Research in Education and Science, 7(2), 445-478. https://doi.org/10.46328/ijres.1805

JaleniauskienL', E. (2016). Revitalizing foreign language learning in higher education using a PBL curriculum. Procedia - Social and Behavioral Sciences, 232, 265-275. https://doi.org/10.1016/j.sbspro.2016.10.014

Jones, G., Robertson, L., Gardner, G. E., Dotger, S., \& Blanchard, M. R. (2012). Differential use of elementary science kits. International Journal of Science Education, 34(15), 2371-2391. https://doi.org/10.1080/09500693.2011.602755

Jumanto, J., Sopandi, W., Kuncoro, Y., Handayani, H., \& Suryana, N. (2018). The effect of radec model and expositorial model on creative thinking ability in elementary school students in Suralaya. ICEE 2018 International Conference on Elementary Education.

Kementerian Pendidikan dan Kebudayaan. (2014). Materi pelatihan implementasi Kurikulum 2013. Badan Pengembangan Sumber Daya Manusia Pendidikan dan Kebudayaan dan Penjaminan Mutu Pendidikan Kementerian Pendidikan dan Kebudayaan.

Küçükoğlu, H. (2013). Improving reading skills through effective reading strategies. Procedia - Social and Behavioral Sciences, 70, 709-714. https://doi.org/10.1016/j.sbspro.2013.01.113

Magulod, G. C. (2018). Innovative learning tasks in enhancing the literary appreciation skills of students. SAGE Open, 8(4), 215824401882038. https://doi.org/10.1177/2158244018820382

Pintrich, P. R., Marx, R. W., \& Boyle, R. A. (1993). Beyond cold conceptual change: the role of motivational beliefs and classroom contextual factors in the process of conceptual change. Review of Educational Research, 63(2), 167-199. https://doi.org/10.3102/00346543063002167

Posner, G. J., Strike, K. A., Hewson, P. W., \& Gertzog, W. A. (1982). Accommodation of a scientific conception: Toward a theory of conceptual change. Science Education, 66(2), 211-227. https://doi.org/10.1002/sce.3730660207

Pratama, Y. A., Sopandi, W., \& Hidayah, Y. (2019). RADEC learning model (read-answer-discussexplain and create): The importance of building critical thinking skills in Indonesian context. International Journal for Educational and Vocational Studies, 1(2). https://doi.org/10.29103/ijevs.v1i2.1379

Rashid, S., \& Qaisar, S. (2016). Developing critical thinking through questioning strategy among fourth grade students. Bulletin of Education and Research, 38(2), 153-168.

Redhead, K. (2018). Common misconception: Electrocity. https://pstt.org.uk/application/files/5915/2717/3121/Common_Misconceptions_Spring_2018. pdf

Riasati, M. J., \& Mollaei, F. (2012). Critical pedagogy and language learning. International Journal of Humanities and Social Science, 2(21), 223-229.

Rohmawatiningsih, W., Sopandi, W., \& Surtikanti, H. K. (2018). The students' conceptual change using poe strategy assisted by air properties-experimental kit. ICEE 2018 International Conference on Elementary Education. http://proceedings.upi.edu/index.php/icee/article/view/93/88

Şahin, Ç., \& Çepni, S. (2011). Developing of the concept cartoon, animation and diagnostic branched tree supported conceptual change text:"gas pressure." International Journal of Physics \& Chemistry Education, 3(SI), 25-33. https://www.ijpce.org/index.php/IJPCE/article/view/112

Sopandi, W. (2017). The quality improvement of learning processes and achievements through the 
read-answer-discuss-explain-and create learning model implementation. Proceeding 8 th Pedagogy International Seminar 2017: Enhancement of Pedagogy in Cultural Diversity Toward Excellence in Education, 8(229), 132-139.

Stefanova, S., Bobkina, J., \& Sánchez-Verdejo Pérez, F. J. (2017). The effectiveness of teaching critical thinking skills through literature in EFL context: A case study in Spain. International Journal of Applied Linguistics and English Literature, 6(6), 252. https://doi.org/10.7575/aiac.ijalel.v.6n.6p.252

Svetlana, T., \& Olga, S. (2017). An enquiry-based approach to develop language skills in mobilesupported classrooms. Journal of Language and Education, 3(3).

Turgut, Ü., Gürbüz, F., \& Turgut, G. (2011). An investigation 10th grade students' misconceptions about electric current. Procedia - Social and Behavioral Sciences, 15, 1965-1971. https://doi.org/10.1016/j.sbspro.2011.04.036

Vlassi, M., \& Karaliota, A. (2013). The comparison between guided inquiry and traditional teaching method. A case study for the teaching of the structure of matter to 8 th grade Greek students. Procedia - Social and Behavioral Sciences, 93, 494-497. https://doi.org/10.1016/j.sbspro.2013.09.226

Vygotsky, L. S. (2012). Thought and language. MIT press.

Widodo, W., Rosdiana, L., Fauziah, A. M., \& Suryanti. (2018). Revealing student's multiplemisconception on electric circuits. Journal of Physics: Conference Series, 1108, 012088. https://doi.org/10.1088/1742-6596/1108/1/012088

Wulandari, W., Wahyu, W., \& Sopandi, W. (2020). Students' creativity in creating aromatherapy candle using petroleum learning design with Radec model. Journal of Educational Sciences, 4(4), 813. https://doi.org/10.31258/jes.4.4.p.813-820 